\title{
DIVINE PRESENCE IN DEUTERONOMY ${ }^{1}$
}

\author{
Ian Wilson
}

\section{Introduction}

The concept of divine Presence in Deuteronomy and related writings is frequently represented by the term 'Name Theology'. It is derived principally from two sets of texts (references to YHWH's Name at the sanctuary and to the location of YHWH himself in heaven), and is related to a perceived emphasis on divine transcendence. While published discussion has generally attempted to elucidate the significance of the various 'Name formulae', usually by means of an appeal to other Ancient Near Eastern material, little attention has been paid to the possibility that the biblical data in relation to divine Presence may have a further contribution to make to the discussion. In particular, the occurrences in legal contexts of the expression לפני יהוה ('before $\mathrm{YHWH}^{\text {') }}$ have frequently been cited against Name Theology, but have been ignored by advocates of the theory and inadequately expounded by its opponents.

This dissertation neither proposes a new interpretation of the Name formulae nor evaluates any of the already-existing proposals. Rather, by examining possible references to divine Presence in the historical and legal sections of Deuteronomy, it queries the adequacy of the aforementioned twofold biblical foundation upon which many such proposals have been predicated.

\section{Divine Presence in the Historical Material}

Much of the historical material is considered to derive from the Deuteronomists, biblical writers generally held to have espoused Name Theology. Assuming, therefore, that at least in their own writings such authors would display a measure of consistency, one would expect their views on divine Presence to be reflected not only in their treatment of the cult, in terms of

1Ian Wilson, Divine Presence in Deuteronomy (Unpublished PhD Thesis, Cambridge University 1992). 
a commitment to divine transcendence, but also in their version of Israel's history.

A number of Deuteronomy's historical sections are therefore examined by means of a series of 'synoptic' comparisons with parallel narratives from Exodus and Numbers. Each passage selected comes from one hand, i.e. according to a source-critical consensus, though no assumptions are made as to relative priority. Hence, the deuteronomistic accounts are compared with J, E and P material, that from the Tetrateuch being viewed purely as a control. In addition, each pair of passages contains at least one expression referring to the earthly Presence of $\mathrm{YHWH}$. Justification for such an interpretation (frequently on the basis of what appears to be a common OT idiom) is generally offered vis-à-vis such expressions in Deuteronomy, but not in Exodus/Numbers. A key example is the divine communication 'out of the midst of the fire' (similar to that in Ex. 3:4).

The purpose of the comparison is twofold: first, to see whether, consistent with Name Theology, the earthly Presence of YHWH has been edited out of the deuteronomistic material. This is achieved by determining the relative emphases on divine Presence in each pair of passages under consideration. Secondly, it is to determine, in those cases where such reference is absent from Deuteronomy, whether its non-inclusion can be understood on the basis of the immediate context, i.e. in terms of the differing concerns of the pericopes involved, without having to appeal to the operation of a conscious theology of transcendence.

The investigation shows that 12 pairs of passages can be regarded as in some way comparable. Five refer to divine Presence in both accounts (in one pair the same construction is used, while in the other four a variety of means is employed), six do so only in Deuteronomy and one does so only in Exodus. In addition there are a further 16 instances of divine Presence (4 in Deuteronomy and 12 in Exodus/Numbers) whose absence from the other account can generally be explained in terms of differing emphases within the narratives. Moreover, Deuteronomy 4:36, which refers to YHWH allowing his voice to be heard from heaven, is shown to locate him both in heaven and on the earth, and so poses no threat to an understanding of his communication from the fire in terms of his localised 
Presence on the mountain. Finally, Deuteronomy's alleged emphasis on the auditory aspects of the divine revelation at Horeb (seen by some scholars as evidence for transcendence), i.e. in contrast to a perceived Exodus emphasis on the visual, is shown to be both inconclusive and without foundation.

\section{III. לפני יהוה in the Legal Section}

Examination of earlier treatments of the expression לפני יהוה as it occurs throughout the Old Testament, reveals a variety of classifications, but a paucity of criteria to which appeal might be made to distinguish between the various interpretations proposed. Our own investigation therefore attempts to establish such criteria, with a view to enabling a distinction to be drawn between the literal and more metaphorical uses of the phrase. In this way it is hoped to determine whether the former meaning, i.e. that of spatial proximity to the Deity, is the main one operating within Deuteronomy 12-26.

After isolation of the clearly metaphorical instances of the expression $(24: 4,13)$, the general characteristics of the remaining 14 are examined. Two features stand out. First, there is the specific application of 'before $\mathrm{YHWH}^{\prime}$ only to that site (the 'chosen place') at which the Name is present, but from which advocates of Name Theology believe YHWH himself to have been absent. Secondly, it is found that whereas the use of לפני is generally consistent with that in the rest of the Old Testament, in five cases out of 13 it is used instead of the preposition most commonly associated with the particular activity proposed in relation to the Deity. Such usage indicates a compliance with Hebrew syntax where little or no choice is involved, but a definite bias in favour of לפני where more than one preposition was available. This implies a deliberate concern to bring לפני יהוה and the 'chosen place' into close association.

Three possible interpretations are then examined. Views of it as a 'linguistic fossil' (Mettinger) or as a circumlocution meaning simply 'at the sanctuary/chosen place' are shown to be inconsistent with the available evidence. Instead, the latter points to an understanding of the expression in terms of the divine Presence localised at the sanctuary.

Finally, each of the activities predicated as taking place in Deuteronomy 12-26 are examined individually: 
eating, rejoicing, standing, speaking, setting down and worshipping. Earlier views are evaluated, usage elsewhere (in relation to both the Deity and humans) is examined, and the various activities considered in context. In most cases OT usage elsewhere suggests the literal interpretation of the phrase, which in the case of 18:7, 19:17 and 26:5 finds additional support in specific features of their immediate context.

\section{Summary}

Within the historical sections of Deuteronomy there are clear indications of divine Presence. There is thus no evidence for the anticipated elimination (or even reduction) of such a notion. Neither is there evidence for any weakening of its mode of expression. A variety of terms is employed, similar to that found in Exodus/Numbers (with the notable exception of ('descend') and the range of anthropomorphisms found in Ex. 33:17-23), and alluding to the Presence of YHWH with varying degrees of directness. Since, therefore, many such terms are embedded in deuteronomistic material, it is clear that in presenting their own version of Israel's past the Deuteronomists felt no qualms about portraying the Deity as being present on the earth. Moreover, the two lines of approach used by others to argue for $\mathrm{YHWH}^{\prime}$ s sole localisation in heaven, i.e. an appeal to 4:36 and the supposed emphasis on the auditory nature of the presentation of events at Horeb, have both been shown to be without foundation.

This absence of any overriding emphasis on divine transcendence is supported by the legal section of the book in which the term לפני יהוה occurs predominantly in its literal sense and thus locates the Deity within the sanctuary.

Such a consistent portrayal of YHWH's relation to the earthly sphere, i.e. in terms of being present, in both historical and legal material, shows that the Deuteronomists cannot have been committed to the idea of a solely transcendent God. The claim, therefore, that the deuteronomic cult envisages $\mathrm{YHWH}$ only in heaven is thus open to serious question, and the existence of a thoroughgoing Name Theology in Deuteronomy becomes increasingly unlikely. It is clear that the significance of the Name at the 'chosen place' will require further investigation. 